\title{
Reading Theories and Reading Comprehension: Review and Discussed
}

\section{Herri Susanto}

\author{
Sekolah Tinggi Teknologi (STITEK) Bontang, \\ herristitek@gmail.com
}

Article History: Submitted December 18 ${ }^{\text {th }}, 2019$; Accepted March $9^{\text {th }}, 2020$; Published March $13^{\text {th }}, 2020$

\begin{abstract}
In this article, several reading theories need to be reviewed in their relationships to read understanding educators and English lecturers. Three other Reading Models, BottomUp, Top-Down, and Interactive, are discussed in the Schema Theory at the theoretical stage. The history of reading training, kinds and purposes of reading, and cognitive reading abilities will be discussed in checking the reading understanding. Finally, it reviews six variables that are engaged in understanding English texts.
\end{abstract}

Keywords: comprehension, models of reading, schema theory

Abstrak. Dalam artikel ini, beberapa teori bacaan perlu ditinjau dalam hubungannya untuk membaca pemahaman para pendidik dan dosen bahasa Inggris. Tiga Model Membaca diantaranyamodel Bottom-Up, Top-Down, dan Interactive dibahas dalam Schema Theory pada tahap teoretis. Rentetan uji coba, jenis dan tujuan membaca, serta kemampuan membaca kognitif dibahas dalam memastikan pemahaman membaca. Akhirnya, terdapat review terhadap enam variabel yang terlibat dalam memahami teks bahasa Inggris.

Kata kunci: membaca, model membaca, teori schema

\section{INTRODUCTION}

This article is a review of theories of reading and understanding of reading addressed in a variety of books, newspapers, articles, and the like. Four primary subjects are discussed here, namely (i) the nature of reading, (ii) the theory of schema, (iii) understanding of reading, and (iv) the factors engaged in understanding.

\section{Nature of Reading}

Reading is an extremely complex process that cannot be satisfactorily explained by anyone. Those interested in reading have their basic varied opinions resulting from two distinct psychology classrooms: behaviorism and cognitive. In this regard, most reading models are partly worried with particular elements (e.g., perceptual or cognitive), phases (start or competent reading), or modes (oral or silent reading). They are not trying to take all elements of the reading process into consideration. No single model was available that could be called the most acceptable. 
Reading is something many of people use it for purposes. People just read with or without on purposes. It is noted that so much of the world's population can read a little more than 80 percent of the world's population can read to some extent. (Grabe, 2012).

\section{Bottom-up Models}

Bottom-up read process models regard reading as essentially a method of translation, decoding, or encoding. The reader starts here with letters or bigger units and begins to anticipate the phrases they spell as he attends to them. They are decoded into inner speech when the words are recognized, from which the reader derives meaning in the same manner as listening. Comprehension of reading is thought to be an automatic result of precise word recognition in this process.

These models ' adherents asserted that reading is fundamentally the translation of graphic symbols into an oral language approximation. These models are affected by behavioral psychology and consequently structural linguistics in which they are mostly suitable for starting readers.

\section{Top-down Models}

The cognitive and language skill of the reader plays a main role in building significance from printed materials in top-down reading models. Friedman (2019) states that in the topdown reading model, the point is placed on a student's engagement with the text. It is insufficient to get students to simply know the word they see, understand its general meaning and know how to pronounce it if reading aloud. The aim of the top-down reading theory is in order to get students to become active readers. Active readers have increased comprehension skills and larger vocabularies and are more capable of engaging in abstract and logical consideration.

\section{Interactive Models}

According to Anthony (2018) she stated that the combination model can be done in connecting between surface structure systems and deep structure systems. The example of surface system like the sensory and bottom-up portion of reading. While the thinking or top-down is the deep structure one. Thus, these aspects of reading are ways to build meaning and memory for all learners.

Readers apply both knowledge of word structure and background knowledge to reflect the texts they read. For example, a student who encounters an unknown word might use surface structure systems like graph phonic, or letter-sound, knowledge to decode the word. A different student might find it easier to use deep structure systems like semantic knowledge, such as meaning and vocabulary, to decode the same unknown word. Every student has connections in various ways. This process validates and supports both methods of understanding, realizing that individual's process information in very different ways.

The nature of the reading assignment therefore shifts as the learners move from less mature to more mature levels. Reading in this situation is not a skill, but a big range of interrelated abilities that progressively evolve over a period of years. It is therefore a complicated method in which the recognition and understanding of written symbols is affected by the 
perceptual abilities of the reader, decoding abilities, experiences, language backgrounds, mind sets, and reasoning abilities. This last model will be further discussed as this model has become the focus of interest in teaching reading for latest theories, studies, and practice. The debate will be dealt with in the theory of schema.

\section{Schema Theory}

All knowledge is gathered into units depends on schema theories. The schemas are these units. In relation to the knowledge itself, data on how to use this expertise is embedded in these knowledge packages. A schema is then a data structure to represent the memory stored generic ideas.

The interpretation method is driven by the principle that all inputs are mapped against some current schema and that all elements of the schema must be consistent with the input data. This principle leads to two fundamental methods of handling data: bottom-up and top-down. The incoming data evokes bottom-up processing, while the information characteristics enter the scheme with the best fit, bottom-up schemes. Schemes are hierarchically arranged in this mode, beginning from the most general at the top to the most specific at the bottom. As these lower-up schemes converge into higher-level ones, they are triggered. Bottom-up processing is therefore called data-driven processing. The interpretation, in other words, is from components to whole.

A significant element of top-down and bottom-up processing is that both should cover concurrently for all levels. Bottom-up processing provides the information required to instantiate or fill out, while top-down processing facilitates assimilation if expected or compatible with the conceptual expectations of the reader.

It has been stated by Fahriany (2014) that comprehension is to make a sense out of text. It is a process of using reader's background knowledge to explain texts for constructing what it is all about. Many reading specialists confirm in the same point of view that the schema theory is one of the reasonable theories of human information processing. Schemata, the plural of schema, are convinced to be the building blocks of cognition. This paper talks about the role of readers' preexisting understanding on linguistics code as well as readers' understanding of the world (schema), which for the case of reading has similar importance of the printed words in the text. It is argued that the more non visual information the reader posses, the less visual information is needed. For teaching and learning, teachers are expected to use different strategies in order to deal with different students' preexisting understanding and schema to maximize students' learning.

Comprehension is built up or constructed from information sources that communicate with each other on the feedback from the written page, according to interactive reading models. Thus, understanding is the method of connecting fresh or incoming data to data that is already stored in the memory. Here, readers connect with their current understanding between the fresh data on the printed page. The fresh data must be allowed to enter and become component of their knowledge shop. In brief schema theory as a theory of teaching that argues language understanding includes an interactive process between the background information of the learner and the text. The reader utilizes top-down processing in an interactive processing when relating what he already understands to the text being processed, and when relating the text being processed to what he already knows, he utilizes bottom-up processing. 


\section{Reading Comprehension}

In terms of reading, psycholinguists proposed a very distinct thinking model. According to them, a modern psycholinguistic view of reading is based on ideas obtained from contemporary linguistics and cognitive psychology. From this view, reading is regarded as a complicated information-processing skill in which the reader is supposed to be an active planner, individual decision-making coordinating a number of skills and strategies to boost understanding.

Mason, et al (2012) mentions that in a modern society, one of the most critical skills needed for successful students or workers is through reading comprehension. For many students with learning disabilities (LD), it takes explicit reading comprehension instruction to develop this valuable skill since they get significant difficulties with understanding what has been read and will require.

Fortunately, a huge research-base of powerful perusing appreciation intercessions for school-matured understudies with LD has been built up in the course of the last 30 or more years. However, gradually, reading abilities also emerged in the initial texts. It has become apparent that the cognitive processes outlined above are involved in effective reading at all stages. It emphasized in the interactive reading period of the 1980s that significance is not fully present in a text waiting for decoding. Instead, significance is developed through text and reader communication. Background information that promotes text understanding has a significant role to play in this reading model. Here comes into play the schema theory that was discussed previously.

The opinion is supported by Snow (2010) that reading comprehension is a complex topic. When students are predicting to get success in comprehension, they requires knowing about themselves such as about what text being read, the task being undertaken, and about the sociocultural context in which the reading is happened. Since reading comprehension shades into learning, constructing a worldview, and disciplinespecific literacy practices, Snow emphasizes that it is hard to establish firm boundaries around comprehension; nevertheless, it is clear that more attention to comprehension is required across the grades. In preschool and primary grades, opportunities for building vocabulary and background knowledge and practicing oral comprehension should be provided while children are learning to decode. In later grades, students need explicit instruction in how texts are constructed and how language cues signal meaning at sentential and discourse levels, as well as practice and support in wrestling with contentrich texts for well-defined and engaging purposes.

Reading comprehension is important for successful functioning in our society. In virtually all instances, the goal of reading is to identify the meaning or message of the text at hand. Doing so involves the execution and integration of many processes. Discussion the underlying cognitive processes that support reading comprehension and link them to the PASS (Planning, Attention, Simultaneous, and Successive processing) theory of intelligence (Kendeou, 2015).

The same opinion is stated by Burns and Kidd (2010) that reading comprehension happened if pupils construct meaning of the written word in an exchange of ideas between themselves and the information in the text. To understand the passage, readers have to use their ability to identify whole passage, impress their 
extensive vocabularies, and utilize comprehension skills and strategies to support their understanding of the printed materials. This needs them to draw upon their prior knowledge and experiences to make connections between their schemata and the information presented in the passage. This interactive process between readers and passage helps readers to comprehend, remember, and use information read and is influenced by readers' goals for reading, motivation, and social context.

When learning to read, developing fluent word recognition is important for enhancing comprehension of text. Both decoding and comprehension demand memory which has a limited capacity. Effort devoted to decoding words detracts from the ability to expend resources on understanding passage. Thus, developing automatized decoding is vital to boost up comprehension. However, a focus on word identification should not be at the expense of an emphasis on developing vocabulary and comprehension skills and strategies. All areas should be developed simultaneously as children learn to read.

The capacity to scan printed words and connect meaning to the words enables children to build literal interpretations of the passage. Furthermore, when the children push to understand the next level of the passage, the children learn to start their prior knowledge to get inferences about what they read. Children reading about a trip to the park will apply information related to their own background knowledge to help them comprehend further. When the information is not stated explicitly, they will rely on what they know based on their experience before. When the connections they make are relevant and accurate, comprehension is fostered automatically. On the other hand, if the connections they do not have enough schemata of their past experiences then the topic are minimal or nonexistent, drawing upon existing schema will limit their understanding. Therefore, children also learn to rely on the red lines they make within the text to make inferences. This is especially helpful when they have limited knowledge about or experience with the topic. (Burns and Kidd, 2010).

\section{The Variables Involved in Comprehension}

According to Ferdosipour and Delavar (2011) that good readers use their capabilities and dispositions at once. They must convey their capabilities whether the capacity of recognizing word, understanding oral language, and province knowledge, together with the reader's motivation, goals, and purposes as important sources of variability in reading comprehension. Such variables have correlation with one another and with the passage to which the reader is opened as determinants of performance on a given reading task.

To some extent, reader variability is a product of the fact that children come from and learn to read in varying sociocultural contexts. People view learning and literacy through social interactions because they appear for how a specific cultural group or discourse community defines the world and transmits this information.

The second variable is the extent to which the reader utilizes tactics such as contextual guessing. A feature of the processing of indigenous readers is prediction of forthcoming input. Many studies support the assertion that students who communicate with text by methods like anticipating, skimming, scanning, and using background understanding understand much better than those who fail to use these approaches. The third variable is the reading objective or the task's nature. 
Task sort determines the sort of policy that is needed. Different goals and abilities require two types of reading strategies, comprehensive and intensive. Extensive reading, generally for pleasure reading, needs the capacity to comprehend key thoughts, discover particular data, and read rapidly. Intensive reading, on the other side, most often as reading for data, needs the capacity to read throughout the text for details, understand the implications, and follow thinking interactions. The fourth variable refers to the duration of the document to be understood. Students are typically provided shorter, edited texts for reading at the start stage. Students who process shorter texts are more likely to use word-for-word processing approaches as memory requirements allow more attention to detail. Some proof indicates that bigger texts may be simpler for learners to understand as they are more cohesive and interesting for learners, although more top-down processing is required for the texts.

In the process of understanding, the fifth variable is linked to the sort of written document submitted. Traditionally, on the grounds of the simplicity of grammatical constructions and the familiarity of vocabulary, the difficulty of texts was assessed. This may be because understanding is tested on the grounds of acceptance of grammar and vocabulary rather than on communication with the message of the text. However, empirical studies indicated that exposure to texts with unfamiliar grammar and vocabulary does not influence understanding considerably. Other variables, such as the quality of the text itself in terms of factual consistency and consistency, as well as learners ' background information and motivation, may be more crucial to educators when choosing texts.

The sixth understanding variable is the treatment of fresh vocabulary. It is recognized that using vocabulary lists with definitions does little to help the reader construct vocabulary or more effectively understand it while reading. In their thematic and discourse relationship to the text, it will be more effective if new words are presented than in their dictionary definitions. Alternatively, the teacher utilizes debate before and after reading to connect text data to the background understanding of the reader. Therefore, in order to properly understand written texts, the teacher should consider the following factors: (1) the student's background knowledge, (2) the strategies used by the student in the task of understanding, (3) the purpose of reading or the nature of the assignment, (4) the duration of the text, (5) the type of text, and (6) the treatment of fresh vocabulary.

\section{CONCLUSION}

The nature of reading, schema theory, reading understanding, and the factors engaged in reading understanding were evaluated during the debate. The three reading models namely Bottom-Up, Top-Down, and Interactive described briefly when debating the nature of reading. Then the theory of schema reinforces what was discussed in the section The Nature of Reading. Three points were discussed in evaluating reading understanding: Reading Instruction History, Reading Types and Purposes, and Cognitive Reading Skills. Lastly, the variables in understanding consist of (1) the significance of context and background awareness in understanding feedback, (2) the degree to which the reader utilizes approaches to understand the text, (3) the intent for reading or the nature of the assignment, (4) the duration of the text submitted for understanding, (5) the type of written text submitted, and (6) the way in which the vocabulary is handled. The writer hopes that this paper will assist those engaged in reading comprehension teaching to broaden knowledge and understanding as well as to develop reading materials. 


\section{REFERENCES}

Anthony, A. (2018).What Is the Interactive Reading Model?. Science Article. Retrieved from https://classroom.synonym.com/interactive-reading-model-13048.html

Burns, M.S. \& Kidd, J.K. (2010). Learning to Read. M.S. Burns, J.K. Kidd, in International Encyclopedia of Education (Third Edition), 2010. Retrieved from https://www.sciencedirect.com/topics/social-sciences/reading-comprehension

Denies, L., McKenna, M.C. \& Miller, J.W.(1989). Project READ:s: Effective Design for Content Area Reading. Journal of Reading, 22(6).

Fahriany.(2014). Schema Theory in Reading Class. IJEE. Indonesian Journal of English Education. IJEE (Indonesian Journal of English Education). Vol. 1. No.1.2014. doi: 10.15408/ijee.v1i1.1192.

Ferdosipour, A. \& Delavar, A. (2011). The Effects of Structural Variables on Reading Comprehension in Expository Text of Persian. Procedia - Social and Behavioral Sciences. 30, 2011, 1027-1030. doi: 10.1016/j.sbspro.2011.10.200.

Friedman, A. (2019). The Top-Down Reading Model Theory. Updated May 10, 2019. Retrieved from https://www.theclassroom.com/topdown-reading-model-theory13028.html

Goodman, K.H. (1967). Reading: A Psycholinguistic Guessing Game. Journal of the Reading Specialist, 6,126-35.

Grabe, William.(2012).The nature of reading: Defining reading. August 2012. 4-20. doi: 10.1017/CBO9781139150484.004

Kendeou, P. (2015). Reading Comprehension and PASS Theory. Panayiota Kendeou in Cognition, Intelligence, and Achievement, 2015. Retrieved from https://www.sciencedirect.com/topics/social-sciences/reading-comprehension

Mason, L. et al . (2012). Highlights in Reading Comprehension Intervention Research for Students with Learning Disabilities. From: International Encyclopedia of Education (Third Edition), 2010. Retrieved from https://www.sciencedirect.com/topics/socialsciences/reading-comprehension.

Snow, C.E. (2010). Reading Comprehension: Reading for Learning. C.E. Snow, in International Encyclopedia of Education (Third Edition), 2010 Retrieved from https://www.sciencedirect.com/topics/social-sciences/reading-comprehension 